\title{
Editorial
}

\section{Hydrometeorology and Hydroclimate}

\author{
Christophe Cudennec, ${ }^{1,2}$ Alexander Gelfan, ${ }^{3}$ Liliang Ren, ${ }^{4}$ and Mohamed Slimani ${ }^{5}$ \\ ${ }^{1}$ Agrocampus Ouest, UMR 1069 SAS, Rennes, France \\ ${ }^{2}$ INRA, UMR 1069 SAS, Rennes, France \\ ${ }^{3}$ Water Problems Institute of Russian Academy of Sciences, Moscow, Russia \\ ${ }^{4}$ Hohai University, Nanjing, China \\ ${ }^{5}$ Institut National Agronomique, Tunis, Tunisia \\ Correspondence should be addressed to Christophe Cudennec; cudennec@agrocampus-ouest.fr
}

Received 24 February 2016; Accepted 2 March 2016

Copyright (C) 2016 Christophe Cudennec et al. This is an open access article distributed under the Creative Commons Attribution License, which permits unrestricted use, distribution, and reproduction in any medium, provided the original work is properly cited.

Meteorology is the main driving force of hydrology along time, from the instantaneous states and processes until the monthly, seasonal, yearly, and sometimes multiyear sequences. Meteorology drives and impacts much of the hydrological flows and storages, thus water balance terms as well as hazards, across a geometric and functional interface. This interface develops within a certain thickness, yet thin regarding the planetary radius and critical for water and other dynamics. This heterogeneous Critical Zone ranges from the bottom of groundwater reservoirs to the top of the tree canopy [1], including surface water liquid and frozen and gaseous flows and storages. Complex space-time effects develop in this critical zone such as orographic and oceanic influences on moisture-precipitation dynamics, hydrogeomorphological structure-function relationships, upstreamdownstream integration, subsystems connectivities, variability interdependences, and scaling issues [2-6]. In some geographic settings, this critical zone is further complexified by extreme conditions of some of the properties, such as dryness or wetness, groundwater geometries and dynamics, cryospheric developments (snow, ice, and permafrost), soil and land covers, water uses, and concentration of waterdriven chemicals.

The hydrometeorological interface is further subject to complex feedback and feedforward effects, from local fluid mechanic and thermodynamic processes themselves to major interactions within the macroscopic oceanic, lacustrine, cryospheric, deep ground, and biospheric and atmospheric interdependences [7-9]. Ongoing reorganizations of these interdependences actually change the general distribution of water across the different compartments and the corresponding geographies, with impacts on physical properties and corresponding potential resources and hazards. These include but are not limited to interaction with greenhouse gases concentration trends underlying climate change, cryospheric shrinkage, changes of the land-ocean interface, individual and cumulative effects of anthropogenic infrastructures, massive groundwater pumping which locally reduces the resilience to drought and globally increases the atmospheric and hydrological circulating water, and accompanying geodetic and subsidence adjustments [10-15]. These are all intertwined, as elementary socioecological crises are symptoms which now appear to be imbedded in the general macroscopic accelerating transformations of the Anthropocene syndrome [16-19]. Intertwining is also emerging across a general nesting, eventually self-organizing, from global and hemispheric dynamics (from the natural oceano-hydrometeorological ones to new globalization ones) to regional and local niches and settings which can be called AnthropoScenes.

In statistical terms, meteorology can be characterized by climate, and statistical hydrology can be jointly analyzed, which distinguishes hydrometeorology and hydroclimate. Changes in climate, in terms of magnitude, statistical distribution, spatial distribution, timing and (a-)synchronicity, and range of variables, can have impacts on hydrological processes and statistics, as well as on associated dynamics such as erosion, pollution, snow and ice, ecohydrology, and water uses. These impacts are also often mixed with the ones of geographic changes $[4,6,8,15,20]$. 
In such a complex setting, enhanced by nonlinearities, retroactions, and coevolutions, identifying change from variability and eventual nonstationarity is a major issue [20-23]. Further, deciphering, fingerprinting, and attributing causes and impacts are complex in the frame of the Anthropocene and thus ultimately of the Water Security issue and Sustainable Development Goals [8, 24-29].

This special issue is aimed as an additional bridge over the interfacing boundaries and call for deeper cooperation from the hydrological community towards the meteorological one. Specific challenges can indeed be identified from the hydrological perspective, all the more thanks to the recently launched agenda setting Panta Rhei initiative on change in hydrology and society of the IAHS-International Association of Hydrological Sciences of the IUGG-International Union of Geodesy and Geophysics of the ICSU $[15,20]$ and thanks to the actual conceptualization of the Anthropocene from the strictly stratigraphic definition [30] to the wider epistemic understanding of ongoing and future socioecological relationships [17-19].

From this perspective, the following specific challenges are of particular interest:

(i) Using historical information, palaeorecords, and forensics of severe events to elucidate past changes in climate and hydrology, including changes in hydrometeorological/climatic extremes.

(ii) Deepening the processes understanding and physical foundation of models, enlarging the frontiers of modeled systems to encompass the critical interfaces and zone, and adapting models to assimilate new observation means and data sources.

(iii) Assessing the dynamic behaviour of hydrometeorological systems in their links and feedback with coevoluting natural/socioeconomic systems and exploring the attribution issue by inversing causal relationships.

(iv) Analyzing changes in patterns of stable/instable dynamical states of hydrometeorological/climatic systems, the contribution of these changes to selforganization of the systems, the emergence of nesting subsystems and coherent scenes, and the nature of adaptation to changing environmental complexity.

(v) Advancing approaches for analyzing predictability of the water cycle processes including interdependences, separating predictable and unpredictable patterns, and dividing inherent epistemic and model-derived limits to predictability.

(vi) Improving the data chain from in situ observation to open access dissemination, interoperability and indicators for accounting, and stewarding and progressing on related targets, especially in the frame of the new global societal project which is now shaping through the Sustainable Development Goals [29], the Paris Agreement related to Climate Change [31], the implementation of Climate Services in nexus with food, disasters, energy, health, and water resources [32], extreme and disastrous events and the Sendai framework [28, 33, 34], and multiple Water Security challenges $[26,27]$.

(vii) Developing interdisciplinary foresight methodologies and feeding comprehensive prospective explorations of the future hydrometeorological/climatic interface in the wider perspective of the critical zone in the Anthropocene and climate change trends $[1,18,35-$ 37].

The papers published in this special issue do all feed the hydrometeorological/climatic bridge, from the whole or continental-scale changing water cycle (X. Feng and $\mathrm{P}$. Houser and J. Yin et al.) and some emblematic water-driven AnthropoScenes (Y. T. Dile et al., G. Li et al., Y. Li et al., and Y. Tang et al.) to some focused studies of physical processes (T. A. McCorkle et al. and B. M. Shrestha et al.), while contributing to several of the specific challenges identified here above: change assessment (G. Li et al., Y. Li et al., and J. Yin et al.), nesting (J. Liu et al.), conjunction of causalities (Y. Tang et al.), and effects of anthropogenic actions (Y. T. Dile et al. and B. M. Shrestha et al.), as applied to a range of hydrometeorological/climatic variables, geographic contexts, and space-time-frequency scales. Several papers submitted, while not published here according to a timely scheduled peer review, were also framing in this rationale and do have the potential to later contribute to the debate and progress. There is no doubt that scientific progress and innovation will be very active in the coming years in the field of hydrology $[3,4,15,38$, 39], not only in its core but also over its numerous complex and changing interfaces, from sociohydrology [20, 36, 37] and the eventually self-organizing processes of the socioecological Anthropocene $[15,18,19]$ to the fragile critical zone, and the changing frontiers between the oceanic, ground, terrestrial flowing and stored cryospheric and atmospheric components of the hydrosphere, among which hydrometeorology and hydroclimate remain key challenges for scientific pluridisciplinarity and for putting new knowledge, methods, and skills into practice through observation, assessment, mitigation, and adaptation [39, 40].

\section{Acknowledgments}

This is a contribution to the Panta Rhei initiative of IAHS. We are grateful to all the authors who contributed to this issue and to all the reviewers whose suggestions have helped to improve the quality of the papers.

\section{Christophe Cudennec Alexander Gelfan Liliang Ren \\ Mohamed Slimani}

\section{References}

[1] T. White, S. Brantley, S. Banwart et al., "The role of critical zone observatories in critical zone science," Developments in Earth Surface Processes, vol. 19, pp. 15-78, 2015.

[2] G. Blöschl and M. Sivapalan, "Scale issues in hydrological modelling: a review," Hydrological Processes, vol. 9, no. 3-4, pp. 251-290, 1995. 
[3] G. Blöschl, M. Sivapalan, T. Wagener, A. Viglione, and H. H. G. Savenije, Runoff Prediction in Ungauged Basins, Cambridge University Press, Cambridge, UK, 2013.

[4] M. Hrachowitz, H. H. G. Savenije, G. Blöschl et al., "A decade of Predictions in Ungauged Basins (PUB)-a review," Hydrological Sciences Journal, vol. 58, no. 6, pp. 1198-1255, 2013.

[5] C. Cudennec and A. de Lavenne, "Hydrogeomorphology-a long-term scientific interface," Hydrology Research, vol. 46, no. 2, pp. 175-179, 2015.

[6] L. Xie, F. Semazzi, A. Hanna, R. Anyah, H. Gao, and Y. He, "Regional climate change: downscaling, prediction, and impact assessment," Advances in Meteorology, vol. 2015, Article ID 290281, 1 page, 2015.

[7] I. Haddeland, J. Heinke, H. Biemans et al., "Global water resources affected by human interventions and climate change," Proceedings of the National Academy of Sciences of the United States of America, vol. 111, no. 9, pp. 3251-3256, 2014.

[8] B. E. Jiménez Cisneros, T. Oki, N. W. Arnell et al., "Freshwater resources," in Climate Change 2014: Impacts, Adaptation, and Vulnerability. Part A: Global and Sectoral Aspects. Contribution of Working Group II to the Fifth Assessment Report of the Intergovernmental Panel on Climate Change, C. B. Field, V. R. Barros, D. J. Dokken et al., Eds., Cambridge University Press, Cambridge, UK, 2014, https://ipcc-wg2.gov/AR5/images/uploads/WGIIAR5-PartB_FINAL.pdf.

[9] M. I. P. de Lima and S. Lovejoy, "Macroweather precipitation variability up to global and centennial scales," Water Resources Research, vol. 51, no. 12, pp. 9490-9513, 2015.

[10] Y. N. Pokhrel, N. Hanasaki, P. J.-F. Yeh, T. J. Yamada, S. Kanae, and T. Oki, "Model estimates of sea-level change due to anthropogenic impacts on terrestrial water storage," Nature Geoscience, vol. 5, no. 6, pp. 389-392, 2012.

[11] B. R. Scanlon, C. C. Faunt, L. Longuevergne et al., "Groundwater depletion and sustainability of irrigation in the US High Plains and Central Valley," Proceedings of the National Academy of Sciences of the United States of America, vol. 109, no. 24, pp. 9320-9325, 2012.

[12] R. G. Taylor, B. R. Scanlon, P. Döll et al., "Ground water and climate change," Nature Climate Change, vol. 3, no. 4, pp. 322329, 2013.

[13] A. F. Van Loon, T. Gleeson, J. Clark et al., "Drought in the Anthropocene," Nature Geoscience, vol. 9, no. 2, pp. 89-91, 2016.

[14] T. Suni, A. Guenther, H. C. Hansson et al., "The significance of land-atmosphere interactions in the Earth system-iLEAPS achievements and perspectives," Anthropocene, vol. 12, pp. 6984, 2015.

[15] H. McMillan, A. Montanari, C. Cudennec et al., "Panta Rhei 2013-2015: global perspectives on hydrology, society and change," Hydrological Sciences Journal, vol. 61, no. 7, pp. 11741191, 2016.

[16] P. J. Crutzen, "Geology of mankind," Nature, vol. 415, no. 6867, p. 23, 2002.

[17] W. Steffen, J. Grinevald, P. Crutzen, and J. McNeill, "The Anthropocene: conceptual and historical perspectives," Philosophical Transactions of the Royal Society A: Mathematical, Physical and Engineering Sciences, vol. 369, no. 1938, pp. 842-867, 2011.

[18] X. Bai, S. van der Leeuw, K. O'Brien et al., "Plausible and desirable futures in the Anthropocene: a new research agenda," Global Environmental Change, 2015.
[19] E. S. Brondizio, K. O'Brien, X. Bai et al., "Re-conceptualizing the Anthropocene: a call for collaboration," Global Environmental Change, 2016.

[20] A. Montanari, G. Young, H. H. G. Savenije et al., "Panta rheieverything flows': change in hydrology and society-the IAHS scientific decade 2013-2022," Hydrological Sciences Journal, vol. 58, no. 6, pp. 1256-1275, 2013.

[21] H. Lins, A Note on Stationarity and Nonstationarity, WMOCHy-AWG, 2012, http://www.wmo.int/pages/prog/hwrp/chy/ chyl4/documents/ms/Stationarity_and_Nonstationarity.pdf.

[22] D. Koutsoyiannis, "Hydrology and change," Hydrological Sciences Journal, vol. 58, no. 6, pp. 1177-1197, 2013.

[23] D. Koutsoyiannis and A. Montanari, "Negligent killing of scientific concepts: the stationarity case," Hydrological Sciences Journal, vol. 60, no. 7-8, pp. 1174-1183, 2015.

[24] J. Rockström, W. Steffen, K. Noone et al., "A safe operating space for humanity," Nature, vol. 461, no. 7263, pp. 472-475, 2009.

[25] C. J. Vörösmarty, P. B. McIntyre, M. O. Gessner et al., "Global threats to human water security and river biodiversity," Nature, vol. 467, no. 7315, pp. 555-561, 2010.

[26] UN-Water, Water Security \& the Global Water Agenda, UNWater Analytical Brief, United Nations University, 2013, http:// www.unwater.org/downloads/analytical_brief_oct2013_web.pdf.

[27] C. Cudennec, S. Demuth, A. Mishra, and G. Young, Eds., Hydrological Sciences and Water Security: Past, Present and Future, vol. 366 of Proceedings of the International Association of Hydrological Sciences (PIAHS), 2015, http://www.proc-iahs.net/366/index.html.

[28] United Nations General Assembly (UNGA), A/RES/69/283. Sendai Framework for Disaster Risk Reduction 2015-2030, 2015, http://www.preventionweb.net/files/resolutions/N1516716.pdf.

[29] United Nations General Assembly (UNGA), Transforming Our World: The 2030 Agenda for Sustainable Development, A/RES/ 70/1, 2015, https://sustainabledevelopment.un.org/content/documents/21252030\%20Agenda\%20for\%20Sustainable\%20Development\%20web.pdf.

[30] C. N. Waters, J. Zalasiewicz, C. Summerhayes et al., “The Anthropocene is functionally and stratigraphically distinct from the Holocene," Science, vol. 351, no. 6269, 2016.

[31] UNFCCC (United Nations Framework Convention on Climate Change), "Adoption of the Paris agreement," 2015, https://unfccc .int/resource/docs/2015/cop21/eng/109r01.pdf.

[32] WMO-GFCS, Implementation Plan of the Global Framework for Climate Services, WMO, 2014, http://www.gfcs-climate.org/ sites/default/files/implementation-plan//GFCS-IMPLEMENTATION-PLAN-FINAL-14211_en.pdf.

[33] A. Ismail-Zadeh, J. Urrutia-Fucugauchi, A. Kijko, K. Takeuchi, and I. Zaliapin, Extreme Natural Hazards, Disaster Risks and Societal Implications, Special Publications of the IUGG, Cambridge University Press, Cambridge, UK, 2014.

[34] C. Cudennec, A. Eicker, P. Pilon, M. Stoffel, A. Viglione, and Z. Xu, Eds., Extreme Hydrological Events, vol. 369 of Proceedings of the International Association of Hydrological Sciences (PIAHS), 2015, http://www.proc-iahs.net/369/index.html.

[35] L. Saito, D. P. Loucks, and W. M. Grayman, "Road to 2050: visions for a more sustainable future," Journal of Water Resources Planning and Management, vol. 138, no. 1, pp. 1-2, 2012.

[36] M. Sivapalan, H. H. G. Savenije, and G. Blöschl, "Socio-hydrology: a new science of people and water," Hydrological Processes, vol. 26, no. 8, pp. 1270-1276, 2012. 
[37] M. Sivapalan, M. Konar, V. Srinivasan et al., "Socio-hydrology: use-inspired water sustainability science for the Anthropocene," Earth's Future, vol. 2, no. 4, pp. 225-230, 2014.

[38] S. A. Archfield, M. Clark, B. Arheimer et al., "Accelerating advances in continental domain hydrologic modeling," Water Resources Research, vol. 51, no. 12, pp. 10078-10091, 2015.

[39] D. Koutsoyiannis, G. Blöschl, A. Bardossy et al., "Joint editorial-fostering innovation and improving impact assessment for journal publications in hydrology," Hydrological Sciences Journal, vol. 61, no. 7, pp. 1170-1173, 2016.

[40] W. Buytaert, A. Mishra, S. Demuth et al., "Climate change and extreme events," Chapter 2/Section 2.3-Climate change and extreme events. The United Nations World Water Development Report 2016 'Water and jobs', 24-26, http://unesdoc.unesco.org/ images/0024/002439/243938e.pdf. 

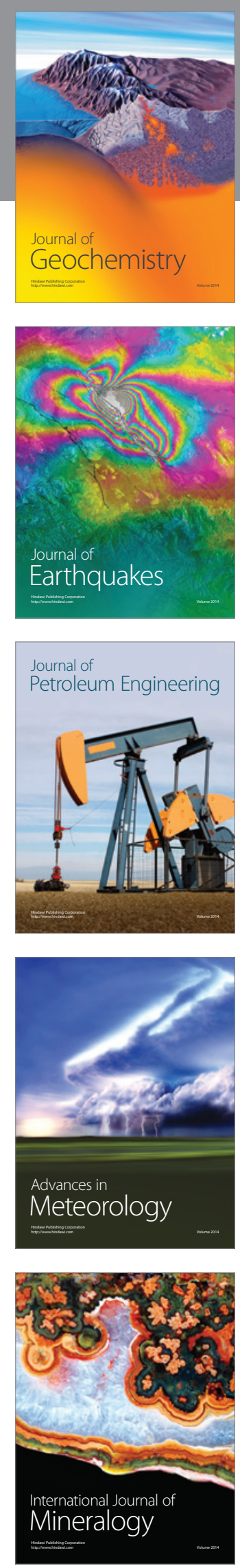
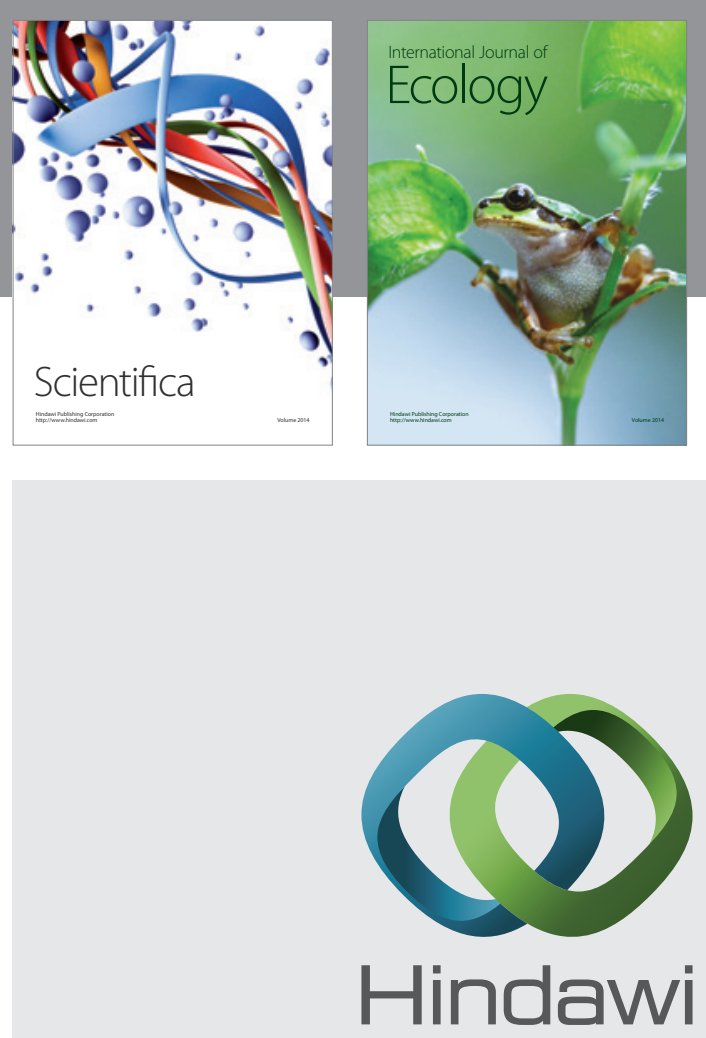

Submit your manuscripts at

http://www.hindawi.com
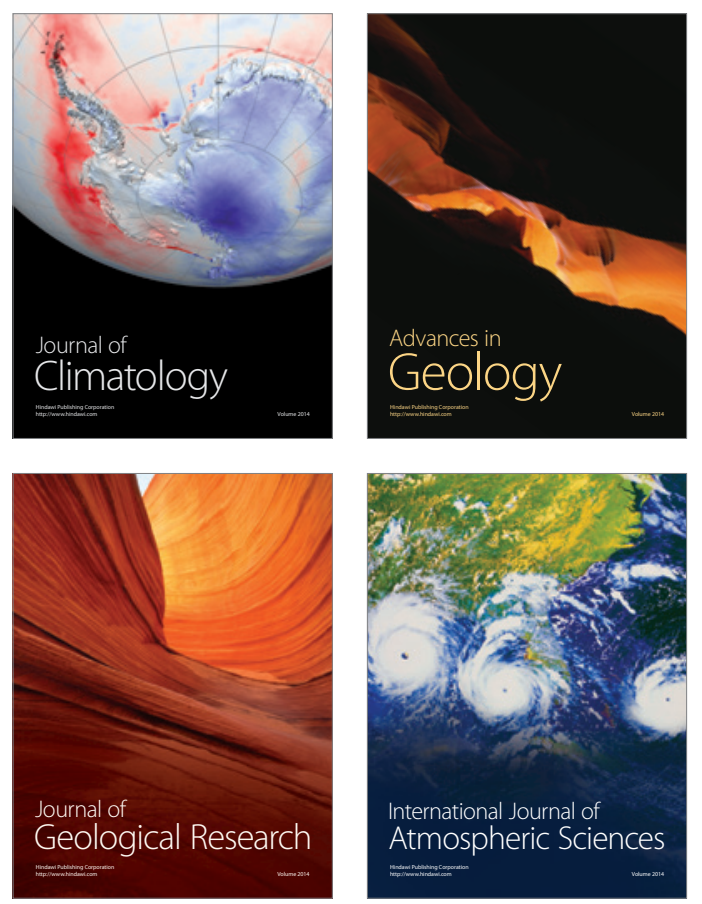

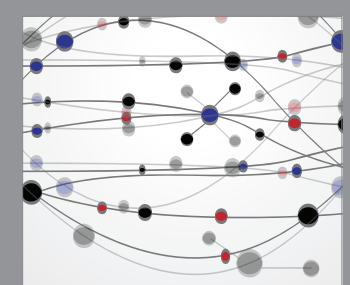

The Scientific

\section{World Journal}
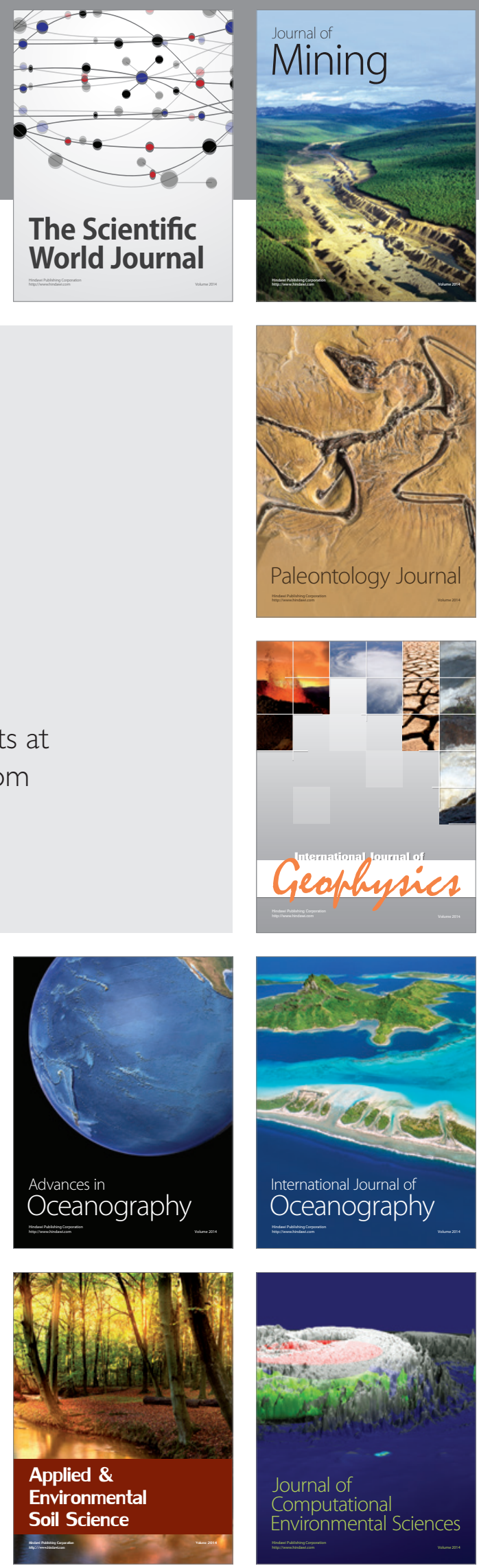